\title{
Study of Availability of Printed Non-Printed Instructional Media in Kindergarten to Develop Students' Reading Interest
}

\author{
Laksmi Dewi, Gema Rullyana, Angga Hadiapurwa \\ Universitas Pendidikan Indonesia, Bandung, Indonesia \\ Corresponding e-mail: laksmi@upi.edu
}

\begin{abstract}
This study focuses on seeing the printed and non-printed instructional media collection, which are available in Early Childhood Education (ECE). The developed reading interest programs are intended to enhance students' reading interest as an effort to improve their reading skills. This study uses a descriptive research method with survey technique. The data were collected from early childhood education institutions available in Kota Bandung. The background of this study is the lack of reading skills of students, from ECE level until higher educations. This has become a drawback when students cannot understand what they read. As ECE is the earliest level of formal education, therefore, it has to contribute to the development of students' reading interest. There are many kinds of fun activities that can be practiced in ECE, which are expected to internalize in students' mind and become their main capital to enter the next level of education.
\end{abstract}

Keywords: Printed Non-Printed Learning Material, Students Reading Interest

\section{INTRODUCTION}

Reading interest should be fostered from young age through a variety of stimuli provided by parents and the surroundings, since this age is considered as the golden age. The Golden Age is a period where a child's brain is able to absorb information quickly. The absorbed information will have a great impact for the child's development. As stated by Howard Gardner, children, during their first five years, are always tinged with success in learning everything, and the growth and development of their brain, heart, and physique are going very well (Widyaiswara, 2015; Roskos, Christie, \& Richgels, 2003).

The importance of introducing early reading interest is to anticipate the decline in students' reading skills. Study shows that reading ability of Indonesian students in general is still relatively low (Suryaman, 2015; Jalal \& Sardjunani, 2006). PIRLS study in 2011 showed that 4th graders in Indonesia are able to answer perfect-level items $(0.1 \%)$, highlevel items (4\%), medium-level items (28\%), and low-level items (66\%) of difficulties level (Suryaman, 2015). This data shows that Indonesian students' ability to answer the perfect-level, highlevel, and medium-level questions are still under the median percentage achieved by international students.

Pros and cons about children's learning become considerable discussion among academics and practitioners. They discuss whether children should be able to read and write, or only allowed to play, and partially introduced to numbers and letters. They also consider about introducing reading. However, the term reading is not necessarily defined as literally recite the text in books or other media. It is perceived as "knowing" the things that exist around the child (Roth \& Paul, 2006; Teale, William, 2009; CFCCH, 2008). Reading program at an early stage is called early literacy.

Early literacy in the early childhood education level should be introduced as early as possible. It is undeniable that nowadays children at the age of 0-6 years are introduced to "reading" through a variety of techniques and media (Roskos, Christie, and Richgels, 2003; Roth \& Paul, 2006; Policy Brief, 2008). Unfortunately, the emerging case of "reading ability" is that children introduced to gadgets that often cause addiction. Even though it is not 
forbidden, however, the parents and teacher should make efforts to teach the children to use the gadget wisely in order to provide them the experiences of living the world.

The existence of Early Childhood Education (ECE) should be able to accommodate the needs of early reading in childhood. Hence, the developed programs should be tailored to the needs and development of children. Through ECE, children are prepared to enter the next level of formal education (Byrnes, in Haryanto, 2012). At this level, children will develop physical, psychological, emotional, and social abilities, in order to shape their personality in facing the future.

ECE institutions have been developed by various parties as an alternative to foster children's development. The programs are intended to stimulate, guide, nurture, and assist, and implement learning processes to optimally develop children's potentials (Tjoe, 2012). The success of ECE institutions in achieving these objectives would need to be supported by a variety of learning facilities and infrastructure. Regarding the implementation, especially in fostering reading interest, many programs have been developed in accordance with the characteristics of kindergarten students, using media such as images, video, audio, and even multimedia. The results of the study show that the media used were very effective to increase children's reading interest and reading ability (Flewitt \& Messer, 2015; Jayanti, A.A Krisna; Lasmawan, Wayan; Sutama, 2013; Tjoe, 2012).

Availability of various media in ECE becomes one of the indicators supporting the successful program implementation of students' reading interests and abilities. Media that are used can provide a variety of alternative techniques, so that the learning process becomes more enjoyable, active, creative, and meaningful (Flewitt \& Messer, 2015; Lynch \& Redpath, 2014; Jayanti, A.A Krisna; Lasmawan, Wayan; Sutama, 2013). Therefore, how does ECE provide a variety of instructional media in developing learning programs that support the development of students' reading interest?

\section{LITERATURE REVIEW}

The role of instructional media in ECE to improve learning outcomes is undoubted. When it is used effectively, it can foster ECE students' reading interest. Hence, various activities that trigger reading interest should be provided to develop reading and writing abilities, in order to make the children express their ideas clearly and understandable.
Using media in ECE is significant to make the learning process more 'lively' and stimulate the activity of thoughts, feelings, attention, and learning interest of students (AECT, 1994; Heinich, Molenda \& Russell, 2002). Since it can improve the learning qualities, therefore a systematic plan in making the media is required to foster reading interest. There are two kinds of media that can be used in ECE, namely printed and non-printed media (Gagne in Zaman \& Eliyawati, 2010), which can be utilized to increase children's reading interest (Flewitt \& Messer, 2015; Lynch \& Redpath, 2014; Jayanti, A.A Krisna; Lasmawan, Wayan; Sutama, 2013; Yulia, 2013).

Seeing the importance using media, therefore ECE institutions should pay more attention to the availability of various kinds of media. However, its selection cannot be unintentional and without clear objective. It should be appropriate with the needs and stated learning objectives, hence the implementation of the learning process will be more effective and efficient (Kustandi \& Sutjipto, 2011). Accordingly, the use of appropriate media can create reading interest and motivation. It is expected that later the students can see the importance of reading and will independently have better plans to keep reading (Cambria \& Guthrie, 2010; Moser \& Morrison, 1998).

The use of media is not only expected to enable the children to read, but also foster early literacy. Its development should be implemented by various parties in Indonesia, as it has been implemented in other countries. It is proven that implementing a well-designed early literacy program can foster reading interest and improve reading skills, namely the ability to understand, analyses, evaluate the results of reading and able to write and deliver information from the reading well (Kennedy, Dunphy, \& Dwyer, 2012). Programs that can support early literacy are teacher talk, storytelling, phonological awareness activities, alphabet activities, and support for emergent reading (Kuger, Rossbach, \& Weinert, 2013; Roskos et al., 2003; Alleyne, 1998).

\section{METHOD}

This study used a qualitative approach with case study method, conducted by observation in 21 ECE/Kindergartens in Bandung. The study instrument is interview, which was used to gather information from the head and teachers of the ECE/Kindergartens, who were all females. The interview was done to discover how the existence of instructional media at the kindergarten support the efforts to foster reading interest. The questions put emphasize on the media provision, learning process 
using the media, and the use of instructional media in supporting the development of children's reading interest. The obtained data were identified, reduced, and presented. Then, the data were verified through discussion among research team members, in order to make sure the data are appropriate with the research purpose. Lastly, drawing the conclusion based on the research findings and related literature.

\section{RESULTS}

\subsection{Instructional Media at ECE}

Following are the analysis results on the instructional media in ECE. This identification is based on indicators developed from the interview guideline instrument. The indicators include the type of media, the number of titles and copies of printed media, the number of titles of non-printed media, procurement processes of the media, and media to support the learning process in ECE. These indicators are expected to provide interpretation of using instructional media in ECE.

The interview guideline grouped the questions into printed and non-printed media. The results show that the use of printed media dominates the learning process. It consisted of books, magazines, flash card (letters and numbers), and others. Some other ECE use non-printed media in the learning process, like blocks, Lego, geometrical shapes, puzzles, other educational toys, audio and video tapes, and musical instruments. In addition to indoor non-printed media, there are also outdoor media such as sport facilities, slides, swings, tree house, and flying fox.

As noted above, the printed media, in this case books and magazines, were the primary or dominant source used in ECE. In selecting the printed media, teachers should pay attention to the level of use and the content of the media, and tailor them to suit student's mastery level. The books that attract students' attention are usually books with pictures, which are expected to attract more attention and increase the children's reading interest. Regarding to the number of titles and copies, on average, the ECE institutions being studied have more than 300 titles, yet still below 1,000 copies. Moreover, the interview also revealed that many of the available books are not appropriate with the learning themes in ECE. It becomes a challenge for ECE teachers to find or create their own printed media.

Some other ECE involved in this study have non-printed media. They have cassettes, videos, educational games, sport facilities, and musical instruments. The number of non-printed media is not many, which challenges the teachers to create a more varied interactive media. Efforts have been made by teachers to utilize various non-printed media, such as using ribbons to make wicker. Making wicker in ECE classroom can train students' fine motor movements.

The use of various media in the learning process in ECE can avoid students' boredom; therefore its provision becomes significant aspects. The government has contributed to the provision of instructional media. The Ministry of Education and Culture, in this case the directorate of ECE has annual program that provides media for ECE institutions. Moreover, cooperation with book publisher can also add the media collection, which is done through proposal submission to the publishers that have more collection of early childhood media. Another way of media provision is by purchasing them independently. It is usually done based on proposals from children, parents, or teachers who understand the students' needs more media. Several institutions provide non-printed media initiated by the teachers. To support this condition, teachers' creativity is required to be more developed.

ECE expects to have a variety of media, both printed and non-printed, that can be used in the learning process. Among the expected print media are picture books, educational magazines, posters, and others, it is discovered that picture books are still lacking in number and they expect more illustrated books that are suitable to the characteristics and needs of students. Besides, there are various posters used in ECE containing information about motivation to learn while playing, to foster character building, and to maintain cleanliness, etc. Regarding to the non-printed media, the ECE institutions wish to have more learning audio and video for young children.

Table 1. Number of Collection

\begin{tabular}{clc}
\hline No & Type of Media & Average Numbers \\
\hline 1 & Printed & 618 \\
\hline 2 & Non-Printed & 22 \\
\hline
\end{tabular}

\subsection{Learning Program}

Learning program is a series of planning, execution, and the assessment of learning outcomes. Instructional media is one of the components related to the program; therefore it should be designed as effective as possible. In this study, the observed learning program are the planning and 
implementation with the use of the media, the role of teachers and the process in developing a medium of learning, the use of media available in ECE, and teachers' idea in developing learning by utilizing instructional media.

Good planning will yield good results, certainly with implementation according to plan. Hence, the teachers should be able to make plans in accordance with the contents delivered. Specifically, teachers are also expected to analyses the availability of existing media or design media that are easily obtained. Based on respondents' opinions, the design of learning programs the use of media is adjusted to the needs and referred curriculum. The syllabus, which is a written plan in curriculum dimension, usually includes the names or types of media that are used. From the syllabus, teacher can follow, modify and create media specified in the written lesson plan.

Concerning the use of media, seen from the data obtained, ECE teachers bring instructional media available in the library or make the media themselves. Its implementation is sometimes tailored to the needs of the class, for example when deciding the theme of learning activities; the instructional media should also be suited to the theme.

Specifically, the defined themes can also be flexible, because the theme can be attributed to a

phenomenon that is occurring around the learners.

In developing the existing media, most teachers develop the media independently. This is done after finding out the shortcomings of the media at the previous meeting. Some teachers develop learning media based on the results of internet search, since there are many websites that provide information on learning media development.

The development process of instructional media is expected to improve the delivery of the material in further learning. In developing the media, most teachers always discuss which classroom needs instructional media the most, since it as fitted to the availability of existing media. There are some creative teachers who utilized existing learning media, for example by utilizing origami paper, kokoru paper; and other creations, such as making pencil ornament, creations based on cartoons and so on. Furthermore, several ECE conduct moving class learning, so the students take turns to use the available media. In addition, teachers can propose ideas to create a new instructional media from available materials to avoid students' boredom. Furthermore, the improvement of teacher competence in making instructional media can be done by following trainings on developing instructional media. The constraints that lead teachers not to independently develop instructional media are limited facilities and knowledge about how to develop instructional media.

Most teachers stated that they utilize instructional media available at the library or other learning resources at the ECE. In this case, the teachers use all available media in the best way that will fit the students' needs. Regarding the provision of instructional media, there is an annual budget for purchasing new instructional media or repairing damaged ones.

Teachers have many ideas to improving learning by utilizing instructional media, such as increasing the number of books that attract students reading interest in order to suit students' daily context. To enhance children's imagination and creativity, teachers develop instructional media of learning while playing and singing with audio cassette guides. Learning development can also be done using instructional media like videos, LCD projectors, so that the students do not get easily bored and can understand what is being described accurately. Associated with utilizing the environment, some ECE make mini zoos and mini parks to stimulate the awareness of animals. In addition, some teachers recycle existing media and develop new games, so that the students are interested to learn something new even though the material has been learned before.

\subsection{Utilization of Instructional Media}

The effort to improve children's reading interest is the responsibility of parents and teachers. Learning activities at the Kindergarten are designed under the principle of fun learning, in which children learn while playing and vice versa. In Kindergarten children reading interest improvement program that is conducted using the whole language approach. Based on thematic learning activities, whole language approach is applied to help improve language development in children including reading skills. The effort to increase reading interest the Kindergarten is focused on the higher level students, or children who are being prepared for the primary school. However, it does not necessarily mean that lower level class does not receive attention in reading interest. Efforts to improve reading interest in children are done through a variety of activities using instructional media; for example vocabulary games and storytelling with supporting media including story books, flash cards, and instructional videos. As an illustration, the theme of the week was 
about the 'profession', through storytelling using books, the teacher explained about the profession of a physician, and as an addition, at the end of the school semester, a doctor was invited to tell the students' in person about the profession of physician. Besides the routine activities in the classroom, Kindergarten also opens an additional program to improve reading interest and skills for children. The program is organized for parents who want their children to be more skilful, or for children who need special treatment in order to improve reading interest and skills. At the end of the semester, some activities such as libraries and museums visits or being visited by professional storytellers are carried out. One of the goals is to stimulate reading interest and improve reading skills in children. Kindergarten consistently implement the reading interest improvement program through various activities, and it must be supported by some other factors such as the provision of appropriate media, both printed and non-printed media. Another contributing factor is the teacher's creativity-the better teachers' creativity means the more qualified learning. Therefore, the school keeps working to improve the teachers' creativity by involving teachers in parenting activities, workshops of utilizing instructional media, scientific workshops, storytelling skills improvement and other activities aimed at improving the creativity of teachers.

\subsection{Discussion}

From observations in the field, 21 schools have an average of 618 collections of printed media, including books, flashcards, posters and magazines, and an average of 22 collections of non-printed media including Lego, blocks, audio and video tapes. The teachers, as the respondents, stated that the numbers of printed and non-printed media are still considered less than ideal for supporting learning in the classroom, whereas it is very important in supporting the learning process. These findings support the statement that the availability of instructional media can support the learning process in the classroom (Flewitt \& Messer, 2015; Jayanti, A.A Krisna; Lasmawan, Wayan; Sutama, 2013). One important aspect in designing learning program in the classroom is the selection of the suitable media. From the findings in the field, teachers develop instructional media independently, some utilize or recycle the media that are already available, and some utilize other learning resources such as libraries in schools in an effort to support the learning process. Teachers stated that instructional media is developed based on the needs of the class. By implementing theme-based curriculum, the variety of the media becomes plenty. Since the teachers are required to make different and interesting instructional media every day, they realize that they must improve their skills in developing instructional media. The selfdevelopment program that can improve their skills are training on utilizing instructional media in ECE, parenting, and exchange ideas with other teachers or making use of internet as a reference in designing and developing instructional media. However, some teachers still experience difficulties in developing instructional media. It is due to limited facilities and limited knowledge in developing instructional media. Teachers affirm that well-designed learning media can make the learning process more "alive", and can also stimulate the mind, feelings, attention, and learning interests of the students. These findings are in line with the statement that the use of instructional media can improve students' level of activity and effect on improving the quality of learning (AECT, 1994; Heinich, Molenda \& Russell, 2002).

The other findings show that appropriately designed instructional media can help increase reading interest in ECE (Flewitt \& Messer, 2015; Lynch \& Redpath, 2014; Jayanti, A.A Krisna; Lasmawan, Wayan; Sutama, 2013; Yulia, 2013); and a systematic plan is required to foster students' learning interest as an effort to improve students' reading interest in early childhood education that can be done through both print and non-print media.

Teachers demonstrate understanding the importance to introduce reading to children at the early age. This in line with the findings that the children's brain, heart, and physique are developing very well, therefore it is appropriate to introduce children to reading from early age (Widyaiswara, 2015; Roskos, Christie, and Richgels, 2003).

Efforts to increase reading interest in ECE are done through a variety of learning activities that are supported by appropriate learning media. Some teachers have showed their skill in utilizing printed and non-printed media and combined them with storytelling technique. The storytelling activities were well-designed: starting from setting up the theme, duration, selecting the media (the selection of appropriate books, to audio and video). This findings is in line with Roskos, Christie, and Richgels (2003); Roth \& Paul (2006); Teale, William (2009); Policy Brief (2008), that children at the age of 0-6 years old are introduced to the "reading" through a variety of techniques and media. 


\section{CONCLUSIONS}

This study shows the availability of the printed and non-printed media ECE, the use of appropriate instructional media (printed and non-printed) in ECE and the use of media to increase reading interest in early childhood education. The findings in this study have affirmed the importance of printed and nonprinted media in ECE. Every school must provide printed and non-printed media based on the current needs of the students. The media should be designed and developed by teachers, thus they are required to have good skills in developing them.

In relation to the study implementation, this study has limitations in generalizing data, such as the availability of printed and non-printed media in ECE, and which type of media should be available in schools. Therefore, further study needs to be conducted with a larger sample, or using quantitative methods like experiments and survey, which can be done to investigate the correlation between the availability of printed and non-printed media in ECE and children's reading interest at an early age.

\section{ACKNOWLEDGEMENTS}

We dedicate this work to our respondents who has/have given use permission to conduct this study.

\section{REFERENCES}

AECT. (1994). Teknologi pendidikan. Jakarta: Rajawali.

Alleyne, C. Jackson. (1998). Early literacy development: A focus on preschool. America: Connecticut State Department of Education.

Centre of Community Child Health. (2008). Policy brief No. 13 2008: Literacy in early childhood. Australia: The Royal Children's Hospital. Retrieved from www.rch.org.au/ccch/policybriefs.cfm

Cambria, J., \& Guthrie, J. T. (2010). Motivating and engaging students in reading. The NERA Journal, 46(1). Retrieved from http://www.literacyconnects.org/img/2013/03/ Motivating-and-engaging-students-in-readingCambria-Guthrie.pdf

Flewitt, R., \& Messer, D. (2015). New directions for early literacy in a digital age : The iPad. http://doi.org/10.1177/1468798414533560
Haryanto. (2012). Pentingnya pendidikan anak usia dini. Retrieved From.

Http://Belajarpsikologi.Com/PentingnyaPendidikan-Anak-Usia-Dini/

Heinich, R., Molenda, M., Russell, J.D, \& Smaldino, S.E.E (200). Instructional Media adnt Technology for Learning, 7th edition. New Jersey; Prentice Hall, Inc.

Jalal, F. \& Sardjunani, N. (2006). Increasing Literacy in Indonesia: In Adult Education and Development. Vol. 67, 131-154.

Jayanti, A.A Krisna; Lasmawan, Wayan; Sutama, I. M. (2013). Penerapan media bermain gambar dalam meningkatkan membaca permulaan kelompok B Tk Dharma Putra Kedonganan tahun ajaran 2012 / 2013. E-Journal Program Pascasarjana Universitas Pendidikan Ganesha, 3, 1-10.

Kennedy, E., Dunphy, E., \& Dwyer, B. (2012). Literacy in early childhood and primary education ( 3-8 years ). Dublin: National Council for Curriculum and Assessment (NCCA). Retrieved from www.ncca.ie

Kuger, S., Rossbach, H. G., \& Weinert, S. (2013). Early literacy support in Institutional settings A cmparison of quality of support at the classroom level and at the Individual child level. In M. Pfost, C. ; Artelt, \& S. Weinert (Eds.), The development of reading literacy from early childhood to adolescence. Empirical findings from the Bamberg BiKS Longitudinal Studies (pp. 64 -92). Deutsche: University of Bamberg Press. Retrieved from http://www.uni-bamberg.de/ubp/

Kustandi, Cecep \& Sutjipto, Bambang. (2011). Media pembelajaran; Manual dan digital. Bogor: Ghalia Indonesia.

Lynch, J., \& Redpath, T. (2014). " Smart” technologies in early years literacy education: A meta-narrative of paradigmatic tensions in iPad use in an Australian preparatory classroom. http://doi.org/10.1177/1468798412453150

Moser, G. P., \& Morrison, T. G. (1998). Reading horizons increasing students' Achievement and interest in reading increasing students ' Achievement and interest in reading. Reading Horison, 38(4). Retrieved from http://scholarworks.wmich.edu/cgi/viewcontent .cgi article $=1264 \&$ context=reading_horizons

Roskos, K. A., Christie, J. F., \& Richgels, D. J. (2003). Early literacy instruction. National association for the education of young children. Retrieved from 
https://www.naeyc.org/files/yc/file/200303/Ess entials.pdf

Roth, Froma P; Paul, Froma. (2006). Emergent

literacy: Early reading and writing

development. Retrieved from

http://www.asha.org/public/speech/emergentliteracy.htm

Suryaman, M. (2015). Litera. Litera, 14(1), 170

186. Retrieved from

journal.uny.ac.id/index.php/litera/article/downl $\mathrm{oad} / 4416 / 3841$

Teale, W. H. (2009). Children learning English and their literacy instruction in urban schools. The Reading Teacher, 62(8), 699-703.

Tjoe, J. O. L. (2012). Peningkatan kemampuan membaca permulaan melalui pemanfaatan multimedia. JURNAL PENDIDIKAN USIA DINI, 7(1), 17-48.

Yulia, L. N. (2013). Pengenalan membaca bagi anak usia dini dengan pendekatan beyond center circle time (BCCT) di Taman KanakKanak Islam Al-Azhar Kota Bukit Tinggi. SPEKTRUM PLS, 1(1), 119-130.

Widyaiswara, Hesty.(2015). Pilih anak menjadi "Bisa atau suka membaca"?. Retrieved fromhttp://m.radarbangka.co.id/rubrik/detail/pe rspektif/10833/pilih-anak-menjadi bisa-atausuka-membaca.html

Zaman, Badru; Ellyawati, Cucu. (2010). Media pembelajaran anak usia dini. Bandung: Universitas Pendidikan Indonesia. A paper (unpublished). 